Check for updates

1 Antimicrobial Resistance Centre London School of Hygiene and

Tropical Medicine, London, UK

2 Liverpool School of Tropical Medicine, Liverpool, UK

3 UK Centre for Ecology and Hydrology, Wallingford, UK

4 University College Dublin, Dublin, Ireland

5 Oxford Martin Schoool, Oxford, UK

Correspondence to: RE Glover rebecca.glover@lshtm.ac.uk Cite this as: BMJ 2022;376:e069999 http://dx.doi.org/10.1136/bmi-2022-069999 Published: 23 February 2022

\title{
Sale of UK's Vaccine Manufacturing and Innovation Centre
}

\author{
Government's decision on vital vaccine infrastructure is baffling and should be reversed
}

Rebecca E Glover, ${ }^{1}$ Adam P Roberts, ${ }^{2}$ Andrew C Singer, ${ }^{3}$ Claas Kirchhelle ${ }^{4,5}$

Amid a surge of infections from the omicron coronavirus variant, revelations about high profile breaches of pandemic restrictions, and deepening tensions between Ukraine and Russia, a puzzling announcement has escaped the attention of many commentators-the UK government has put its Vaccine Manufacturing and Innovation Centre (VMIC) up for sale.

Launched in 2018 and only just completed, the centre is the jewel in the crown of the UK's covid-19 vaccine response. ${ }^{12}$ The UK taxpayer spent over £2oom on the centre, a joint venture between the University of Oxford, the London School of Hygiene and Tropical Medicine, Imperial College London, and industry partners. ${ }^{3}$ The non-profit facility was meant to help UK researchers and small and medium enterprises move promising vaccines to production and provide a bulwark against future pandemics, vaccine shortages, and price wars. ${ }^{4}$

The wisdom of this investment became obvious in April 2020, when funding for the VMIC and other public initiatives was ramped up, and construction of a $74000 \mathrm{~m}^{2}$ facility began as scientists raced to develop the Oxford-AstraZeneca covid-19 vaccine. ${ }^{5}$ As recently as March 2021, the government described the VMIC as a "highly specialist facility" that can "respond to pandemics by producing millions of doses quickly."3

So why is this key UK vaccine infrastructure being sold off?

According to the government, industry has effectively taken over production of covid-19 vaccines, and "the need for VMIC’s surge capacity has passed.” ${ }^{1}$ Although availability remains a major problem globally, it is true that large pharmaceutical companies are now producing billions of vaccine doses and that these same companies should be able to update vaccines to respond to emerging variants. Meanwhile, selling off the VMIC will generate treasury revenue at a time of fiscal pressure.

\section{Short sightedness}

However, is this really making the best use of public money? Or is it another case of what the former head of the UK Vaccine Task Force, Kate Bingham, recently described as the government's neglect of biological threats and lack of strategic scientific expertise in decision making?

As highlighted by numerous commentators, including Bingham, ${ }^{6}$ maintaining robust vaccine research, development, and manufacturing capabilities should be a cornerstone of any national security strategy. Cultivating such a complex infrastructure requires long term funding and political backing. The development of the technologies underlying current adenovirus and mRNA vaccines took decades-and future pandemics may require different technological solutions.

Expecting industry to make the necessary long term investments is naive. The history of vaccination includes numerous examples where a mix of short term industrial priorities and lack of long term political planning compromised the ability of research, development, and manufacturing hubs to attract private and public investment, retain skilled workers, and respond to emerging and re-emerging disease threats. ${ }^{7}$ The UK experienced a substantial loss of vaccine capabilities during the 1980 s and 1990s, for example, after leading players such as the Wellcome Foundation and Glaxo pulled out of or relocated centres of vaccine expertise to other countries. $^{8}$

The VMIC, which was conceived before the pandemic, was a sign of renewed political ambition and confidence in the UK's vaccine infrastructure. Situated at the intersection of public and private research and providing a vital bridging function for both, the centre offers a cost effective way to retain and adapt staff and skills to meet current and future threats. Its ability to rapidly produce enough promising products for phase II and III clinical trials without lengthy negotiations with external investors and manufacturers could greatly accelerate vaccine development in the UK and serve as a model for public infrastructure investment in other global health challenges such as antibiotic innovation. ${ }^{9}$

Worryingly, statements by the Department of Business, Energy and Industrial Strategy (BEIS), which oversaw the substantial public investment in the VMIC, indicate that the UK government is distancing itself from the centre and its sale, with little explanation or transparency. ${ }^{10}$ Meanwhile, bidders-which include Oxford Biomedica, Fuji Film, and the Lonza Group-are relative unknowns in vaccine development. The loss of the VMIC at this time is arguably akin to defunding fire brigades after extinguishing a major blaze.

Economically, selling the VMIC without parallel improvements to strengthen the upstream innovation that led to much of the UK's early covid-19 vaccination successes makes little sense. Revenues from the sale of VMIC will have little or no effect on the biggest rise in national debt since the second world war.

Reputationally and strategically, the damage may be even worse. Coming just after a U turn on a 100 million dose vaccine contract with French-Austrian company Valneva that caused production to move 
from Scotland to Germany, selling the VMIC signals a lack of government commitment that will deter investors who may wish to build British biomedical capacity-an important goal of post-Brexit strategic planning. ${ }^{11}$

Since the decision to sell off the VMIC during a pandemic seems difficult to justify on strategic, public health, economic, or reputational grounds, it would be foolhardy to proceed with it. The government is entertaining offers for the VMIC, but it has not yet accepted any, to our knowledge. Until it is sold, there remains an opportunity for the UK public and its elected members of parliament to convince those in charge to protect what could well become a cornerstone of British pandemic preparedness and bioindustrial infrastructure.

Competing interests: We have read and understood BMJ policy on declaration of interests and declare that REG is affiliated with LSHTM, which is a partner in the VMIC. REG has no involvement in the VMIC.

Provenance and peer review: Not commissioned; externally peer reviewed.

1 Thomas H. Sale of UK vaccine centre smacks of short memory syndrome. Financial Times 2021 Nov 30. https://www.ft.com/content/2986f544-b3b6-4fa5-9dff-fea9132be466

2 Oxford vaccine and research centre worth $f 200 \mathrm{~m}$ could be sold. BBC News 2022 Jan 9. https://www.bbc.com/news/uk-england-oxfordshire-59927667

3 Department of Health and Social Care. Extra $£ 47.6$ million for Vaccines Manufacturing and Innovation Centre. Press release, 20 Mar 2021. https://www.gov.uk/government/news/extra476-million-for-vaccines-manufacturing-and-innovation-centre

4 Mancini DP, Kuchler H, Pickard J, Cameron-Chileshe J. Flagship UK vaccine manufacturing centre put up for sale. Financial Times. 2021 Nov 29. https://www.ft.com/content/d312c4cb-201d-4ce6a98f-715b20d77998

5 Cross S, Rho Y, Reddy H, etal. Who funded the research behind the Oxford-AstraZeneca covid-19 vaccine?BMJ Glob Health 2021;6:e007321. doi: 10.1136/bmjgh-2021-007321 pmid: 34937701

6 University of Oxford. "Another war is coming," Kate Bingham DBE, delivers Romanes lecture. 2021. https://www.ox.ac.uk/news/2021-11-24-another-war-coming-kate-bingham-dbe-deliversromanes-lecture

7 Blume S, Baylac-Paouly B, eds. Immunization and states: the politics of making vaccines. Routledge, 2021.

8 Dougan $\mathrm{G}$. How we lost our vaccine manufacturing industry and why we should get it back; a personal perspective. Gordon Dougan's blog, 28 Jan 2021. https://gordon-

dougan.blog/2021/01/28/how-we-lost-our-vaccine-manufacturing-industry-and-why-we-shouldget-it-back-a-personal-perspective

9 Glover RE, Singer AC, Roberts AP, Kirchhelle C. NIMble innovation-a networked model for public antibiotic trials. Lancet Microbe 2021;2:e637-44doi: 10.1016/S2666-5247(21)00182-8

10 UK Parliament. Vaccine Manufacturing and Innovation Centre (VMIC). Written questions, answers and statements. May 2021 to Feb 2022. https://questions-statements.parliament.uk/writtenquestions?Answered=Any\&AnsweredFrom=\&AnsweredTo=\&DateFrom=11\%2F05\%2F2021\&DateTo=31\%2F07\%2F2022\&Expanded=True\&House $=$ Commons\&SearchTerm=vmic

11 Grierson J, Davies R. UK cancels covid vaccine deal with French firm Valneva. Guardian2021 Sep 13. https://www.theguardian.com/world/2021/sep/13/uk-cancels-covid-vaccine-deal-french-firmvalneva

This article is made freely available for personal use in accordance with BMJ's website terms and conditions for the duration of the covid-19 pandemic or until otherwise determined by BMJ. You may download and print the article for any lawful, non-commercial purpose (including text and data mining) provided that all copyright notices and trade marks are retained. 